\title{
A RESPONSABILIDADE CIVIL DO ESTADO POR CONDUTA OMISSIVA
}

\author{
JoÃo AGNALDO DONIZETI GANDINI* \\ Diana Paola da Silva Salomão*
}

1. INTRODUÇÃO - 2. A RESPONSABILIDADE CIVIL - 2.1. Evolução histórica - 2.2. Conceito de responsabilidade - 2.3. Conceito de responsabilidade civil - 2.4. Finalidade - 2.5. Espécies de responsabilidade civil - 2.5.1. Responsabilidade subjetiva ou Teoria da Culpa - 2.5.2. Responsabilidade objetiva ou Teoria do Risco -- 2.6. Elementos da responsabilidade civil - 2.6.1. Conduta - 2.6.2. Dano - 2.6.3. Nexo de causalidade - 2.6.4. Culpa - 3. A RESPONSABILIDADE CIVIL DO ESTADO - 3.1. Introdução - 3.2. Evolução histórica da responsabilidade do Estado - 3.3. Excludentes da responsabilidade do Estado - 3.4. Caracteres da conduta ensejadora de responsabilidade do Estado - 4. RESPONSABILIDADE CIVIL DO ESTADO DECORRENTE DE CONDUTA OMISSIVA 4.1. Introdução - 4.2. A responsabilidade estatal subjetiva por conduta omissiva defendida por Celso Antônio Bandeira de Mello - 4.3. A Responsabilidade estatal objetiva por conduta omissiva defendida pela doutrina e jurisprudência majoritárias - 4.4. Considerações sobre a natureza objetiva da responsabilidade estatal por conduta omissiva - 4.5. O principio da legalidade e a conduta omissiva - 4.6. A falta do serviço e o Código de Defesa do Consumidor - 5. CONCLUSÕES - 6. REFERENNCIAS BIBLIOGRÁFICAS.

\section{Introdução}

A doutrina e a jurisprudência brasileiras ainda não se pacificaram acerca da natureza da responsabilidade civil do Estado por conduta omissiva. A divergência gira em torno do questionamento sobre a revogação tácita, ou derogação, do artigo

* Juiz de Direito Titular da 9a Vara Cível da Comarca de Ribeirão Preto/SP, Mestre em Direito pela Unesp e Professor da Faculdade de Direito da Universidade de Ribeirão Preto.

** Advogada e Bacharel em Direito pela Universidade de Ribeirão Preto.

R. Dir. Adm.,

Rio de Janeiro, 232: 199-230,

Abr./Jun. 2003 
15 do Código Civil de 1916 [art. 43 do novo Código Civil], frente ao artigo 37. parágrafo $6^{\circ}$, da Constituição Federal de 1988.

Sobre o assunto há duas posições, uma seguindo os argumentos de Oswaldo Aranha BANDEIRA DE MELLO, continuada por Celso Antônio BANDEIRA DE MELLO, que defende que a responsabilidade do estado por conduta omissiva tem natureza subjetiva, com base legal no artigo 15 do antigo Código Civil, restando, portanto, como de natureza objetiva apenas a responsabilidade por condutas comissivas. Outra defende a teoria da responsabilidade objetiva tanto para a conduta comissiva como para a omissiva, aplicando-se, para ambos, a norma do artigo 37 , parágrafo $6^{\circ}$, da Constituição Federal.

Atualmente, essa divergência vem alcançando o Poder Judiciário, causando um entrave no curso dos processos, em razão das discussões sobre qual a natureza jurídica da responsabilidade do Estado por condutas omissivas que geraram danos.

Para maior entendimento da responsabilidade do estado por condutas omissivas, devemos traçar preliminarmente algumas considerações sobre a responsabilidade civil privada e geral, pelo que as desenvolveremos nos itens seguintes, posto que a responsabilidade do Estado é responsabilidade civil, à qual são aplicados, todavia, princípios peculiares.

\section{A responsabilidade civil}

\subsection{Evolução histórica}

Nos primórdios da civilização humana, a responsabilidade civil fundava-se na vingança coletiva, que se caracterizava pela reação conjunta do grupo contra o agressor, pela ofensa a um de seus componentes. O instituto evoluiu para uma reação individual, ou seja, passou da vingança coletiva para a privada, em que os homens faziam justiça pelas próprias mãos, fundamentados na Lei de Talião, que é conhecida até hoje pela expressão "olho por olho, dente por dente". O poder público, neste caso, intervinha apenas para ditar como e quando a vítima poderia ter o direito de retaliação, ensejando no lesante dano idêntico ao que foi produzido.

No antigo Direito Romano prevaleceu a noção básica do delito, no qual a vingança privada tornou-se o fator genético que pairava sob a idéia predominante de responsabilidade, não se distanciando, com isso, das civilizações que precederam.

Numa segunda etapa surgiu a idéia da composição voluntária, prevalecendo o entendimento de que seria mais racional a reparação do dano por meio da prestação da poena e outros bens [pagamento de certa quantia em dinheiro], do que cobrar a pena de Talião. Após essa fase, surgiu a da composição legal, em que o ofensor era punido pelo Estado de modo muito tímido, como a ruptura de um membro, a fratura de um usso. ofensas ordinárias como violências leves, bofetadas, golpes etc.

A evolução do tema só ocorreu com a introdução, nos conceitos jus-romanísticos, da Lex Aquilia de Damno, que promanou dos tempos da República e sedimentou a idéia de reparação pecuniária, em razão do valor da res. 
Com relação à culpa, há algumas controvérsias entre os autores a respeito de suas origens. De um lado, sustentam que a idéia de culpa era estranha à Lei Aquilia; de outro, afirmam que esta lei não a negava, defendendo sua presença como elementar na responsabilidade civil [In Lege Aquilia et levissima culpa venit].

A teoria da responsabilidade se concretizou por intermédio da doutrina, principalmente a desenvolvida pelos juristas franceses DOMAT e POTHIER, responsáveis pelo Princípio da Responsabilidade Civil e que influenciou quase todas as legislações que se fundaram na culpa.

Foram surgindo certo princípios gerais e a responsabilidade civil evoluiu sob o prisma de seu fundamento, baseando-se o dever de reparar o dano não somente quando houvesse culpa, esta denominada responsabilidade subjetiva, como também pela Teoria do Risco, passando aquela a ser objetiva, sob a idéia de que todo risco deve ser garantido, independentemente da existência de culpa ou dolo do agente causador do dano.

A respeito, temos os comentários de Carlos Roberto GONÇALVES:

A responsabilidade objetiva funda-se num princípio de eqüidade, existente desde o Direito Romano: aquele que lucra com a situação deve responder pelo risco ou pelas desvantagens dela resultantes (ubi emolumentm, ibi onus: ubi commoda, ibi incommoda). Quem aufere os cômodos (ou lucros), deve suportar os incômodos (ou riscos) $)^{1}$

Quanto à indenização, impera o princípio da responsabilidade patrimonial, ou seja, o lesante responde com o seu patrimônio pelos prejuízos causados a terceiros. deverá haver plena e total reparação dos direitos do lesado [restitutio in integrum], até onde suportarem as forças do patrimônio do devedor, ensejando uma compensação pelo prejuízo sofrido.

No direito brasileiro existiram três fases distintas. Na primeira, as Ordenações do Reino sustentavam-se no direito romano, aplicando-o como subsidiário do direito pátrio, devido à chamada Lei da Boa Razão [Lei de 18 de Agosto de 1769]. A segunda fase concentrou-se no Código Criminal de 1830, que promanou com a idéia de "satisfação", ou seja, o ressarcimento do dano, o que é usado até hoje. Já a terceira fase distinguiu a responsabilidade civil da penal, concentrando a satisfação do prejuízo decorrente do delito na legislação civil.

\subsection{Conceito de responsabilidade}

O vocábulo "responsabilidade" originou-se do verbo latino respondere, que vem a ser o fato de alguém se constituir garantidor de algo. Por sua vez, tal verbo latino teve raízes na palavra spondeo, também de origem latina, que era a fórmula pela qual se vinculava, no direito romano, o devedor nos contratos verbais.

1 GONÇALVES, Carlos Roberto. Responsabilidade civil. 6. ed. São Paulo: Saraiva, 1995, p. 6. 
A origem da palavra "responsabilidade" não nos auxilia no seu conceito atual, uma vez que seu significado original seria a "posição daquele que não executou o seu dever" ${ }^{2}$, ou, ainda, a idéia de fazer com que se atribua a alguém, em razão da prática de determinado comportamento, um dever ${ }^{3}$. Juridicamente relevante seria a responsabilidade imposta àquele que, com sua conduta comissiva ou omissiva, violou bem juridicamente protegido, gerando para ele uma sanção.

Como bem salientou Serpa LOPES:

A violação de um direito gera a responsabilidade em relação ao que a perpetrou. Todo ato executado ou omitido em desobediência a uma norma jurídica, contendo um preceito de proibição ou de ordem, representa uma injúria privada ou uma injúria pública, conforme a natureza dos interesses afetados, se individuais ou coletivos ${ }^{4}$.

Podemos afirmar que a responsabilidade pode se apresentar sob vários aspectos, sendo ela de natureza civil, penal ou administrativa. Ateremo-nos, entretanto, somente à responsabilidade civil, que é o cerne de nosso estudo.

\subsection{Conceito de responsabilidade civil}

A responsabilidade civil pode ser conceituada sob um novo enfoque, observado pelo jurista Francisco AMARAL:

A expressão responsabilidade civil pode compreender-se em sentido amplo e em sentido estrito. Em sentido amplo, tanto significa a situação jurídica em que alguém se encontra de ter de indenizar outrem a própria obrigação decorrente dessa situação, ou, ainda, o instituto jurídico formado pelo conjunto de normas e princípios que disciplinam o nascimento, conteúdo e cumprimento de tal obrigação. Em sentido estrito, designa o específico dever de indenizar nascido do fato lesivo imputável a determinada pessoa ${ }^{5}$.

2 DINIZ, Maria Helena. Curso de direito civil brasileiro. 12. ed. aum. atual. São Paulo: Saraiva, 1998, v. 7, p. 33.

3 RODRIGUES, Silvio. Direito civil. 14. ed. São Paulo: Saraiva, 1995, p. 5.

4 LOPES, Miguel de Serpa. Curso de direito civil. 8. ed. rev. atual. Rio de Janeiro: Freitas Bastos, 1996, v. 8, p. 550-551.

5 Direito civil. 2. ed. Rio de Janeiro: Renovar, 1998, p. 531. O citado autor segue dizendo que o instituto da responsabilidade civil traduz a realização jurídica de um dos aspectos do personalismo ético, segundo o qual ter responsabilidade, ser responsável, é assumir as consequiências do próprio agir, em contrapartida ao poder de ação consubstanciado ná autonomia privada. Não mais a concepção egoística do indivíduo em si, mas o indivíduo como pessoa, comprometido com o social. A responsabilidade civil traduz, portanto, o dever ético-jurídico de cumprir uma prestação de ressarcimento. 
A amplitude do conceito de responsabilidade civil revela dificuldades em se ater numa só definição que seja, porque a doutrina tende a unir os conceitos técnicos e a realidade concreta da obrigação de reparar os danos, independentemente de serem identificadas à causalidade, à teoria subjetiva ou à objetiva.

O campo da responsabilidade civil é amplo, já que não se trata de instituto jurídico exclusivo do Direito Civil, pois está bem inserido no corpo da Teoria Geral do Direito, daí sofrer naturais adaptações conforme aplicado no direito público ou privado, porém sempre mantendo a sua unidade jurídica ${ }^{6}$. Há quem sustente, ainda, que a responsabilidade civil é parte integrante do direito obrigacional, pois sempre visa a fazer com que o autor do ato indenize a vítima pelos prejuízos a ela causados.

\subsection{Finalidade}

A responsabilização civil tem por finalidade precípua o restabelecimento do equilíbrio violado pelo dano. Por isso, há em nosso ordenamento jurídico a responsabilidade civil não só abrangida pela idéia do ato ilícito, mas também há o ressarcimento de prejuízos em que não se cogita da ilicitude da ação do agente ou até da ocorrência de ato ilícito, o que se garante pela Teoria do Risco, haja vista a idéia de reparação ser mais ampla do que meramente o ato ilícito.

O princípio que sustenta a responsabilidade civil contemporânea é o da restitutio in integrum, isto é, da reposição do prejudicado ao status quo ante. Neste diapasão, a responsabilidade civil possui dupla função na esfera jurídica do prejudicado: a) mantenedora da segurança jurídica em relação ao lesado; b) sanção civil de natureza compensatória.

\subsection{Espécies de responsabilidade civil}

A responsabilidade civil apresenta-se sob várias espécies, conforme a perspectiva analisada. São elas:

1) Quanto ao seu fato gerador, poderá ser:

a) Responsabilidade contratual: proveniente de conduta violadora de norma contratual;

b) Responsabilidade extracontratual ou aquiliana: resultante da violação de um dever geral de abstenção, de respeito aos direitos alheios legalmente previstos.

2) Quanto ao agente, poderá ser:

a) Responsabilidade direta: proveniente de ato do próprio responsável;

b) Responsabilidade indireta: provém de ato de terceiro, vinculado ao agente ou de fato de animal ou coisa inanimada sob sua guarda.

3) Quanto ao seu fundamento, poderá ser:

6 Acrescenta, ainda, Maria Helena DINIZ: "Por repercutir em todas as atividades humanas, múltiplos são os dissídios doutrinários e díspares são os posicionamentos dos tribunais", op. cit. nota 2, p. 03. 
a) Responsabilidade subjetiva: presente sempre o pressuposto culpa ou dolo. Portanto, para sua caracterização devem coexistir os seguintes elementos: a conduta, o dano, a culpa e o nexo de causalidade entre a conduta e o dano.

b) Responsabilidade objetiva: não há a necessidade da prova da culpa, bastando a existência do dano, da conduta e do nexo causal entre o prejuízo sofrido e a ação do agente. A responsabilidade está calcada no risco assumido pelo lesante, em razão de sua atividade.

A responsabilidade objetiva, por ser a adotada para a responsabilização do Estado por danos causados por seus agentes, será adiante exposta mais detalhadamente.

\subsubsection{Responsabilidade subjetiva ou Teoria da Culpa}

O fato é um pressuposto material da existência do direito, sendo um fenômeno perceptível, que resulta de uma atividade humana ou da natureza. agindo sob o mundo exterior.

Os fatos podem ser naturais ou jurídicos. Fato natural é um acontecimento qualquer, abrangendo os fatos dependentes e não dependentes da conduta humana, ou seja, que contam ou não com a participação do homem para sua ocorrência. O fato jurídico é o acontecimento que marca o começo ou o término de relações jurídicas, possibilitando a conservação, modificação ou extinção de direitos.

Os fatos humanos, também chamados de atos jurídicos, são conceituados como sendo todo comportamento apto a gerar efeitos jurídicos. Dentre eles, há o ato jurídico lícito, ou, simplesmente, ato lícito, e os atos jurídicos ilícitos ou atos ilícitos.

$\mathrm{O}$ ato lícito é causa geradora de obrigação, como o contrato e a declaração unilateral de vontade. $\mathrm{O}$ ato ilícito, a princípio, pressupõe culpa lato sensu do agente, ou seja, a intenção do agente de prejudicar outrem. a violação de um direito, o prejuízo causado por negligência, imprudência ou imperícia.

O Código Civil de 1916, em seu art. 159, asseverava que:

Art. 159. Todo aquele que, por ação ou omissão voluntária, negligência ou imprudência, violar direito ou causar prejuízo a outrem, fica obrigado a reparar o dano. A verificação da culpa e a avaliação da responsabilidade regulam-se pelo disposto neste Código (arts. 1.518 a 1.532 e 1.537 a 1.553 ).

No novo Código Civil tal regra foi dividida em mais de um artigo, constante na Parte Geral, Livro III, Título III ["Dos Atos Ilícitos"], e na Parte Especial, Livro I, Título IX ["Da Responsabilidade Civil"]. Na nova redação, foram modificadas e inseridas algumas palavras, a fim de deixar mais clara a intenção do legislador, além de inserir o posicionamento jurisprudencial já pacífico de que haverá responsabilidade por dano moral independente da existência cumulativa de dano material [art. 186 in fine], bem como o abuso do direito como ato ilícito [art. 187] e o conceito de responsabilidade objetiva [parágrafo único do art. 927]: 
Art. 186. Aquele que, por ação ou omissão voluntária, negligência ou imprudência, violar direito e causar dano a outrem, ainda que exclusivamente moral, comete ato ilícito.

Art. 187. Também comete ato ilícito o titular de um direito que, ao exercê-lo, excede manifestamente os limites impostos pelo seu fím econômico ou social, pela boa fé ou pelos bons costumes.

Art. 927. Aquele que, por ato ilícito (arts. 186 e 187), causar dano a outrem, fica obrigado a repará-lo.

Parágrafo único. Haverá obrigação de reparar o dano, independentemente de culpa, nos casos especificados em lei, ou quando a atividade normalmente desenvolvida pelo autor do dano implicar, por sua natureza, risco para os direitos de outrem.

A imputabilidade da conduta do agente, em face do citado art. 159 do antigo Código Civil e art. 186 c.c. 927 , caput, do novo Código, sobressalta como elemento subjetivo do ato ilícito. Da mesma forma, se o ato do agente não for voluntário, seja por ação, seja por omissão, ou, ainda, se o evento danoso é proveniente de caso fortuito, força maior ou de outra causa de exclusão de responsabilidade, excluída está a responsabilidade ${ }^{7}$

Como podemos observar, no direito brasileiro a responsabilidade civil comum não se desvencilhou do princípio fundamental da culpa, pois o art. 159 do antigo Código Civil, bem como art. 186 c.c. 927 , caput, do novo Código, disciplinam que a vítima que sofreu um dano tem direito a sua reparação, e, portanto, o ofensor tem o dever de repará-lo. O dever de reparação só prosperará se a culpa for extraída da conduta danosa.

Do exposto, sobressaem os seguintes elementos da responsabilidade civil subjetiva: 1) a conduta; 2) o dano; 3) a culpa e' 4) o nexo de causalidade entre a conduta e o dano.

\subsubsection{Responsabilidade objetiva ou Teoria do Risco}

A regra geral é a responsabilidade civil aquiliana ou subjetiva. Porém, nossa legislação, com finalidade protetiva, criou certas exceções, aplicando em determinados casos a responsabilidade objetiva.

Esta, por sua vez, elimina de seu conceito o elemento culpa, ou seja, haverá responsabilidade pela reparação do dano quando presentes a conduta, o dano e o nexo de causalidade entre estes.

A evolução que a teoria objetiva provocou se deu pelo fato da facilitação da ação da vítima em concreto na reparação do dano, gerando aos infratores a obrigação de indenizar por acidentes provenientes de suas atividades, em detrimento da teoria subjetiva, para a qual o agente precisa salientar a culpa dentro da idéia de desvio de conduta.

Vide art. 188 do novo Código Civil. 
A prova acaba sendo de difícil constatação, criando grandes óbices à vítima, que quase sempre acabava arando com os respectivos ônus. Com a técnica da presunção de culpa, impõe-se a inversão do ônus da prova, em razão da condição menos favorável da vítima.

\subsection{Elementos da responsabilidade civil}

\subsubsection{Conduta}

A responsabilidade civil, tanto objetiva como subjetiva, deverá sempre conter como elemento essencial uma conduta.

Maria Helena DINIZ assim a conceitua: "Ato humano, comissivo ou omissivo, ilícito ou lícito, voluntário e objetivamente imputável, do próprio agente ou de terceiro, ou o fato de animal ou coisa inanimada, que cause dano a outrem, gerando o dever de satisfazer os direitos do lesado" 8 .

Sílvio RODRIGUES, por outro lado, somente considera como pressuposto da responsabilidade a ocorrência de um ato ilícito", diferentemente de Maria Helena DINIZ que abarca em seu conceito também os atos lícitos. Para aquele autor, seria pressuposto a ação ou omissão do agente, que "decorre sempre de uma atitude, quer ativa, quer passiva, e que vai causar dano a terceiro. A atitude ativa consiste em geral no ato doloso ou impudente, enquanto a passiva, via de regra, se retrata através da negligência. [...] A omissão só ocorre quando o agente, tendo o dever de agir de determinada maneira, deixa de fazê-lo" 10 .

Portanto, podemos dizer eu conduta seria um comportamento humano, comissivo ou omissivo, voluntário e imputável. Por ser uma atitude humana exclui os eventos da natureza; voluntário no sentido de ser controlável pela vontade do agente, quando de sua conduta, excluindo-se, aí, os atos inconscientes ou sob coação absoluta; imputável por poder ser-lhe atribuída a prática do ato, possuindo o agente discernimento e vontade e ser ele livre para determinar-se.

\subsubsection{Dano}

O dano representa uma circunstância elementar ou essencial da responsabilidade civil, presente em ambas as teorias anteriormente citadas. Configura-se quando há lesão, sofrido pelo ofendido, em seu conjunto de valores protegidos pelo direito, relacionando-se a sua própria pessoa [moral ou física] aos seus bens e direitos. Porém, não é qualquer dano que é passível de ressarcimento, mas sim o dano injusto, contra ius, afastando-se daí o dano autorizado pelo direito.

Para o dano ser passível de indenização há a necessidade de apuração de alguns requisitos: atualidade, certeza e subsistência. O dano atual é aquele que efetivamente

Op. cit. nota 2, p. 37 .

9 Op. cit. nota 3, p. 5 . No mesmo sentido AMARAL, Francisco, op. cit. nota 5, p. 523.

10 Op. cit. nota 2, p. 302. 
já ocorreu. O certo é aquele fundado em um fato certo, e não calcado em hipótese. A subsistência consiste em dizer que não será ressarcível o dano que já tenha sido reparado pelo responsável.

O dano poderá ser patrimonial ou moral. Patrimonial é aquele que afeta o patrimônio da vítima, perdendo ou deteriorando total ou parcialmente os bens materiais economicamente avaliáveis. Abrange os danos emergentes [o que a vítima efetivamente perdeu] e os lucros cessantes [o que a vítima razoavelmente deixou de ganhar], conforme normatizado no art. 1.059 do antigo Código Civil, referendado no art. 402 do novo Código. Já o dano moral corresponde à lesão de bens imateriais, denominados bens da personalidade [ex. honra, imagem etc.].

O dano também pode ser reflexo ou em ricochete, correspondendo ao fato de uma pessoa sofrer, por reflexo, um dano, que primariamente foi causado a outrem, p. ex., separanda que deixa de receber pensão alimentícia em razão da superveniente incapacidade física do ex-marido, esta decorrente de ato ilícito praticado por terceira pessoa ${ }^{\prime \prime}$.

\subsubsection{Nexo de causalidade}

O nexo de causalidade consiste na relação de causa e efeito entre a conduta praticada pelo agente e o dano suportado pela vítima.

Nem sempre é tarefa fácil buscar a origem do dano, visto que podem surgir várias causas, denominadas concausas, concomitantes ou sucessivas. Quando as concausas são simultânea ou concomitantes a questão resolve-se com a regra do artigo 1.518 do antigo Código Civil, regra também presente no novo Código, em seu art. 942, que estipula a responsabilidade solidária de todos aqueles que concorram para o resultado danoso.

Porém, diante da problemática a respeito das concausas sucessivas, surgiram três teorias a respeito:

a) Teoria da equivalência das condiçōes ou dos antecedentes ou conditio sine qua non: estipula que existindo várias circunstâncias que poderiam ter causado o prejuízo, qualquer delas poderá ser considerada a causa eficiente, ou seja, se suprimida alguma delas, o resultado danoso não teria ocorrido, ex. se um pessoa é atropelada, a causa pode ser a imperícia do condutor, mas também a constituição débil da vítima, a natureza do pavimento sobre o qual esta foi projetada, a demora de seu transporte para o hospital, a falta de meios adequados para o seu tratamento etc. Essa teoria, se aplicada de forma isolada, leva a resultados absurdos, provocando infinitamente responsabilidades.

b) Teoria da causalidade adequada: para esta teoria, a causa deve ser apta a produzir o resultado danoso, excluindo-se, portanto, os danos decorrentes de circunstâncias extraordinárias, ou seja, o efeito deve se adequar à causa.

11 PEREIRA, Caio Mário da Silva. Responsabilidade civil. 8. ed. Rio de Janeiro: Forense, 1998, p. 42; SAMPAIO, Rogério Marrone de Castro. Direito civil: responsabilidade civil. São Paulo: Atlas, 2000, p. 91. 
c) Teoria da causalidade imediata ou dos danos diretos e imediatos: para esta é preciso que exista entre o fato e o dano uma relação de causa e efeito direta e imediata. Esta é a teoria adotada pelo nosso ordenamento jurídico, prevista no art. 1060 do antigo Código Civil, bem como no art. 403 do novo Código. Portanto, será causa do dano aquela que está mais próxima deste, imediatamente [sem intervalo] e diretamente [sem intermediário] ${ }^{12}$.

A culpa exclusiva da vítima, a culpa de terceiro, o caso fortuito ou a força maior, a cláusula de não indenizar, as excludentes de ilicitude, o estado de necessidade e a legítima defesa retiram o nexo causal, por isso serão estudados mais detalhadamente. adiante. Importante também salientar que a coincidência não implica em causalidade.

\subsubsection{Culpa}

A culpa, para a responsabilização civil, é tomada pelo seu vocábulo lato sensu, abrangendo, assim, também o dolo, ou seja, todas as espécies de comportamentos contrários ao direito, sejam intencionais ou não, mas sempre imputáveis ao causador do dano.

Apesar de o legislador brasileiro não os definir, podemos dizer que a culpa strictu sensu seria a violação de um dever, legal ou contratual, por imprudência, negligência ou imperícia, e o dolo seria a violação de tais deveres intencionalmente, buscando o resultado que aquele ato irá causar ou, ainda, assumindo o risco de produzi-lo.

A culpa estaria presente somente nas responsabilizações civis decorrentes de atos ilícitos, segundo a orientação adotada pelo Código Civil pátrio, uma vez que as responsabilidades provenientes de atos lícitos não exigem tal pressuposto.

Francisco AMARAL, reportando-se a René SAVATIER, traz como pressupostos da culpa: a) um dever violado [elemento objetivo], b) culpabilidade ou imputabilidade do agente [elemento subjetivo]. Acrescenta, ainda, que este último se desdobra em dois elementos; a) possibilidade, para o agente, de conhecer o dever [discernimento]; b) possibilidade de observá-lo [previsibilidade e evitabilidade do ato ilícito] ${ }^{13}$.

\section{A responsabilidade civil do estado}

\subsection{Introdução}

Já é pacífico o entendimento de que o ordenamento jurídico brasileiro admite que o Estado possa causar prejuízos aos seus administrados, através de comporta-

12 AMARAL, Francisco, op. cit. nota 5, p. 528; PEREIRA, Caio Mário da Silva, op. cit. nota 11 , p. 75 e segs; SAMPAIO, Rogério Marrone de Castro, op. cit. nota 11, p. 80; GONÇALVES, Carlos Roberto, op. cit. nota 1, p. 372.

13 SAVATIER, René apud AMARAL, Francisco, op. cit. nota 5, p. 525. No mesmo sentido RODRIGUES, Silvio. op. cit. nota 3. p. 305; DINIZ, Maria Helena, op. cit. nota 2, p. 39. 
mentos lícitos ou ilícitos, comissivos ou omissivos, resultando-lhe a obrigação de recompor tais danos.

A responsabilidade do Estado obedece a um regime próprio, compatível com sua situação jurídica. pois potencialmente tem o condão de proporcionar prejuízos macroscópicos. Ademais, os administrados não têm poderes para diminuir a atuação do Estado, no âmbito de seus direitos individuais.

Para Celso Antônio BANDEIRA DE MELLO, a responsabilidade do Estado está implícita na noção do Estado de Direito, não havendo necessidade de regra expressa para firmar-se isto. posto que no Estado de Direito todas as pessoas, de direito público ou privado, encontram-se sujeitas à obediência das regras de seu ordenamento jurídico. Desta forma, presente também está o dever de responderem pelos comportamentos violadores do direito alheio.

Hely Lopes MEIRELES utiliza o termo "responsabilidade da administração", pois entende que o dever de indenizar se impõe à Fazenda Pública ${ }^{14}$.

\subsection{Evolução histórica da responsabilidade do Estado}

Num primeiro momento vigia o princípio da irresponsabilidade do Estado, na época dos Estados despóticos ou absolutistas. O raciocínio que imperava era o de que se o Estado é o guardião da legislação, o chefe do executivo não atentaria contra essa mesma ordem jurídica, já que ele a representava.

A irresponsabilidade do Estado era justificada da seguinte forma: o Estado, por ser pessoa jurídica, não tem vontade própria; o Estado age por intermédio de seus funcionários; por isso, quando há a ocorrência de algum ato ilícito a responsabilidade recai no funcionário, já que este é o executor do ato; quando os funcionários agem fora dos parâmetros legais presume-se que não agiram como funcionários, daí a irresponsabilidade do Estado.

Combatiam-se tais idéias com os seguintes argumentos: o Estado possui vontade autônoma, pois a teoria da fixação legal foi superada; o Estado, como pessoa dotada de capacidade, incorre em culpa in eligendo e in vigilando com relação aos seus funcionários; o Estado é sujeito de direitos e obrigações.

Em fins do século XVIII, logo após a Revolução Francesa, em que as revoltas provocaram vários danos a bens particulares, surgiu a diferenciação entre atos de gestão e atos de império, como uma técnica jurídica com a finalidade de minimizar os prejuízos que poderia ter de arcar o tesouro francês, já praticamente insolvente. Assim, os atos de gestão seriam aqueles em que o Estado prática como se fosse um particular, quando administra seu patrimônio. Os atos de império [ou atos de mando] seriam os que o Estado pratica no exercício do poder de polícia, eu lhe é inerente.

Ante essa diferenciação, surgiu a teoria de que só pelos atos de gestão cabe ação indenizatória, pois não se pode questionar a soberania do Estado. Por outro lado, é

I4 MEIRELES, Hely Lopes. Direito administrativo brasileiro. 23. ed. atual. São Paulo: Malheiros, 1998, p. 530. 
imprescindível a ocorrência da culpa do funcionário, explicitada na imprudência, negligência ou imperícia, como condição para responsabilização daquele.

Posteriormente, houve o surgimento da teoria da culpa civilística, que aplicava à responsabilidade do Estado a mesma regra do direito privado, ou seja, deveria haver culpa do agente estatal para que se configurasse a responsabilização do ente público. Com isso, num primeiro momento apenas o funcionário responderia perante o lesado e, somente num segundo momento, também o Estado.

Dentre dessa evolução surgiu a teoria da faute du service, trazendo a idéia de que a culpa seria do serviço público e não mais do agente estatal, ou seja, haveria a responsabilidade do Estado ainda que o servidor faltoso não fosse identificado, pois a responsabilidade daquele viria da falha do serviço em si, porque este não funcionara ou funcionara mal ou tardiamente. Assim, a culpa não era presumida, pois o lesado deveria provar o inadequado funcionamento do serviço público.

Por fim, houve o surgimento da teoria do risco administrativo, na qual o Estado deveria indenizar o dano não somente quando este resultasse de culpa do agente estatal ou de falha do serviço, que seriam os atos ilícitos, mas também os resultantes de atos lícitos, visto que não era mais a culpa do serviço ou do servidor que gerava essa responsabilidade, mas sim o risco que toda atividade estatal implicaria para os administrados.

Desta forma, o Estado seria responsabilizado sempre que sua atividade configurasse um risco para o administrado, independentemente da existência ou não de culpa e desde que desse risco tivesse resultado um dano. A responsabilidade, portanto, passou a ser objetiva. O lesado somente precisava provar a conduta do agente estatal, o dano e o nexo de causalidade entre ambos.

Importante mencionarmos o surgimento da Teoria do Risco Integral, que focaliza o tema sob prismas atuais e avançados. Para essa teoria, o Estado fica obrigado a indenizar todo e qualquer dano, ainda que resultante de culpa ou dolo da vítima.

Entretanto, essa teoria não é muito aceita por vários países, por ser considerada a modalidade extrema da doutrina do risco administrativo, por isso abandonada, na prática, bem como por conduzir ao abuso e à iniqüidade social.

Nosso ordenamento jurídico foi acompanhando essa evolução, adotando as teorias predominantes em cada época, com exclusão da Teoria do Risco Integral, apesar de alguns autores sustentarem o contrário, divergindo da larga maioria da doutrina e da jurisprudência ${ }^{15}$.

O antigo Código Civil, de 1916, em seu art. 15 [art. 43 do novo Código], estatuiu que o Estado será civilmente responsável pelos atos ilícitos praticados por seus representantes, que nessa qualidade causarem danos a alguém.

Porém, por volta da década de 30 predominava o entendimento de que os atos delitivos que gerassem danos, praticados pelos representantes do Estado que exce-

15 Indenização - Furto de veículo estacionado livremente, à noite, em via pública - Inocorrência da denominada faute du service, quando o Poder Público devia agir ou não agiu, agiu mal ou tardiamente - Ordenamento jurídico, ademais, que não adotou a teoria do risco integral — Verba indevida - Inteligência do art. $37, \$ 6^{\circ}$, da CF (TJSP - RT 782/235). 
dessem nas suas funções, não geravam a responsabilidade do Estado, visto que aqueles perdiam a qualidade de prepostos deste e este não concorria para o evento danoso. Portanto, o agente respondia pessoalmente. Adotava-se tal teoria porque naquela época ocorreram inúmeras revoluções, como é o caso da Revolução de 1932, em que o Estado era irresponsabilizado nos casos de excesso culposo ou doloso dos militares.

Foi a partir da Constituição Federal de 1937, em seu artigo 158, que o Estado passou a responder objetivamente pelos atos de seus funcionários, independentemente da existência ou não da culpa do Estado, fundamentada esta responsabilidade na teoria do risco. Com o advento da atual Constituição de 1988 houve uma ampliação da responsabilidade estatal, haja vista o preposto do Estado deixar de ser apenas o funcionário público para ser o agente público, termo este que abrange um número maior de pessoas.

A responsabilidade civil do Estado, considerada pela teoria do risco administrativo, conduz a pessoa jurídica de direito público à reparação do dano sofrido pelo particular por conduta da administração, segundo o princípio da repartição equiitativa dos ônus e encargos públicos a todos da sociedade, num sentido de socialização dos prejuízos oriundos daquela conduta.

\subsection{Excludentes da responsabilidade do Estado}

A responsabilidade civil do Estado será elidida quando presentes determinadas situações, aptas a excluir o nexo causal entre a conduta do Estado e o dano causado ao particular, quais sejam a força maior, o caso fortuito, o estado de necessidade e a culpa exclusiva da vítima ou de terceiro.

A força maior é conceituada como sendo um fenômeno da natureza, um acontecimento imprevisível, inevitável ou estranho ao comportamento humano, p. ex., um raio, uma tempestade, um terremoto. Nestes caos, o Estado se torna incapacitado diante da imprevisibilidade das causas determinantes de tais fenômenos, o que, por conseguinte, justifica a elisão de sua obrigação de indenizar eventuais danos, visto que não está presente aí o nexo de causalidade ${ }^{16}$.

Importante ressaltar que se o Estado deixar de realizar ato ou obra considerada indispensável e sobreviver fenômeno natural que cause danos a particulares pela falta daquele ato ou obra. portanto conduta omissa, o Poder Público será o responsável pela reparação de tais prejuízos, visto que neste caso estará presente o nexo de causalidade entre o ato omissivo e o dano. Desta forma, a causa do dano não é o fato de força maior, mas o desleixo do Estado em, sendo possível prever tal fenômeno e suas conseqüências, nada ter feito para evitá-las.

Já na hipótese de caso fortuito o dano decorre de ato humano, gerador de resultado danoso e alheio à vontade do agente, embora por vezes previsível. Por ser um acaso, imprevisão, acidente, algo que não poderia ser evitado pela vontade

16 MUKAI. Toshio. Direito administrativo sistematizado. São Paulo: Saraiva, 1999, p. 530. 
humana, ocorre, desta forma, a quebra do nexo de causalidade, daí a exclusão da responsabilidade diante do caso fortuito.

A força maior e o caso fortuito estão previsto no artigo 1.058 do antigo Código Civil, bem como no art. 393 do novo Código. Porém, tais normas não os definiram separadamente, o que vem provocando na seara jurídica uma divergência quanto às suas definições, alguns os conceituando exatamente ao contrário do acima exposto, que é a posição da corrente dominante.

O estado de necessidade é também causa de exclusão de responsabilidade, pois traduz situação em que prevalece interesse geral sobre o pessoal e até mesmo individual - princípio da supremacia do interesse público, caracterizado pela prevalência da necessidade pública sobre o interesse particular. Ocorre quando há situações de perigo iminente. não provocadas pelo agente, tais como guerras, em que se faz necessário um sacrifício do interesse particular em favor do Poder Público, que poderá intervir em razão da existência de seu poder discricionário.

A culpa exclusiva da vítima ou de terceiro é também considerada causa excludente da responsabilidade estatal, pois haverá uma quebra do nexo de causalidade, visto que o Poder Público não pode ser responsabilizado por um fato a que, de qualquer modo, não deu causa. Decorre de um princípio lógico de que ninguém poderá ser responsabilizado por atos que não cometeu ou para os quais não concorreu.

Nos casos em que se verifica a existência de concausas, isto é, mais de uma causa ensejadora do resultado danoso, praticadas simultaneamente pelo Estado e pelo lesado, não haverá excludente de responsabilidade. Haverá, sim, atenuação do quantum indenizatório na medida da participação no evento.

\subsection{Caracteres da conduta ensejadora de responsabilidade do Estado}

A responsabilidade civil do Estado poderá ser proveniente de duas situações distintas, a saber: a) de conduta positiva do Estado, isto é. comissiva, no sentido de que o agente público é o causador imediato do dano; b) de conduta omissiva, em que o Estado não atua diretamente na produção do evento danoso, mas tinha o dever de evitá-lo, como é o caso da falta do serviço nas modalidades em que o serviço não funcionou ou funcionou tardiamente, ou ainda, pela atividade que se cria a situação propiciatória do dano porque expôs alguém a risco.

Celso Antônio BANDEIRA DE MELLO classifica as várias hipóteses de comportamento estatal comissivo. que lesa juridicamente terceiros; são eles: a) comportamentos lícitos: a. 1) atos jurídicos; a.2) atos materiais; b) comportamentos ilícitos: b.1) atos jurídicos, ex. a decisão de apreender, fora do procedimento ou hipóteses legais, a edição de jornal ou revista; b.2) atos materiais, ex. o espancamento de um prisioneiro, causando-lhe lesões definitivas ${ }^{17}$.

17 MELLO, Celso Antônio Bandeirà de. Curso de direito administrativo. 10. São Paulo: Malheiros, 1998. p. 623-624. 


\section{Responsabilidade civil do estado decorrente de conduta omissiva}

\subsection{Introdução}

É certo que o estado poderá causar danos aos administrados por ação ou omissão. Porém, nos casos de conduta omissiva, há entendimentos diversos no sentido de que esta não constitui fato gerador da responsabilidade civil do Estado, visto que nem toda conduta omissiva retrata uma desídia do Estado en cumprir um dever legal.

Seria o Estado responsável civilmente quando este somente se omitir diante do dever legal de obstar a ocorrência do dano, ou seja, sempre quando o comportamento do órgão estatal ficar abaixo do padrão normal que se costuma exigir. Desta forma, pode-se afirmar que a responsabilidade estatal por ato omissivo é sempre decorrente de ato ilícito, porque havia um dever de agir imposto pela norma ao Estado que, em decorrência da omissão, foi violado.

Para ser apurada a responsabilidade do Estado por conduta omissiva deve-se indagar qual dos fatos foi decisivo para configurar o evento danoso, isto é, qual fato gerou decisivamente o dano e quem estava obrigado a evitá-lo. Desta forma. o Estado responderá não pelo fato que diretamente gerou o dano, ex. enchente, mas sim por não ter ele praticado conduta suficientemente adequada para evitar o dano ou mitigar seu resultado, quando o fato for notório ou perfeitamente previsível.

Primeiramente, importante ressaltar que até a Constituição de 1946, para a responsabilização do Estado era aplicada a regra do artigo 15 do Código Civil de 1916, numa primeira fase, regida por princípios privatísticos e, noutra, por princípios publicísticos, fundados na "falta do serviço".

A partir da Constituição Federal de 1946, adotou-se no nosso ordenamento jurídico a Teoria da Responsabilidade Objetiva, para a responsabilização do Estado.

Não se tem dúvidas quanto ao cabimento da aplicação desta teoria objetiva na responsabilidade decorrente de condutas comissivas, porém diferentemente ocorre com relação às condutas omissivas, pois surgiu na doutrina e jurisprudência brasileiras uma polêmica discussão a respeito de seu cabimento, nos casos de responsabilização decorrente de conduta omissiva estatal.

A respeito, temos duas posições, uma que segue os argumentos de Celso Antônio BANDEIRA DE MELLO, que defende a teoria da responsabilidade subjetiva, cuja base legal era a aplicação do artigo 15 do antigo Código Civil ${ }^{18}$, e outra, sustentada por vários autores, que defende a teoria da responsabilidade objetiva, aplicando-se, por conseguinte, o artigo 37 , parágrafo $6^{\circ}$, da Constituição Federal.

18 Artigo 15 do Código Civil: “'As pessoas jurídicas de direito público são civilmente responsáveis por atos dos seus representantes que nessa qualidade calusem danos a terceiros, procedendo de modo contrário ao direito ou faltando a dever prescrito por lei, salvo o direito regressivo contra os causadores do dano." 
Para Celso Antônio BANDEIRA DE MELLO deve ser aplicada a Teoria Subjetiva à responsabilidade do Estado por conduta omissiva. Para isso, argumenta o autor que a palavra "causarem" do artigo 37 parágrafo $6^{\circ}$ da Constituição Federal somente abrange os atos comissivos, e não os omissivos, afirmando que estes últimos somente "condicionam" o evento danoso.

Comentando o supracitado artigo constitucional, ensina:

De fato, na hipótese cogitada, o Estado não é o autor do dano. Em rigor, não se pode dizer que o causou. Sua omissão ou deficiência haveria sido condição do dano, e não causa. Causa é o fato que positivamente gera um resultado. Condição é o evento que não ocorreu, mas que, se houvera ocorrido. teria impedido o resultado ${ }^{19}$.

Maria Helena DINIZ também entende que a teoria subjetiva é a que deverá ser aplicada aos casos de responsabilidade do Estado por conduta omissiva, haja vista ter-se a necessidade de ser avaliada a culpa ou o dolo. Ensina, ainda, que o artigo 15 do antigo Código Civil foi modificado somente em parte pelo artigo 37, parágrafo $6^{\circ}$, da Constituição Federal ${ }^{20}$.

Corroborando os ensinamentos acima, a ilustre doutrinadora Odília Ferreira da LUZ entende que:

Isso não significa, necessariamente, adoção da tese objetiva com exclusividade, pois ainda existe a responsabilidade decorrente da falta do serviço, que é a regra; na verdade, coexistem a responsabilidade objetiva e a subjetiva, esta fundada na faute de service e não mais na culpa do agente público (a não ser nos casos em que o Estado se iguale juridicamente ao administrado $)^{21}$.

Entre estes juristas também estão Caio TÁCITO e Themístocles Brandão CAVALCANTI. O próprio Aguiar DIAS, embora manifeste preferência pela responsabilidade objetiva, admite que predomina a teoria subjetiva quando da falta do serviço ${ }^{22}$.

Encontramos, também, algumas decisões dos tribunais brasileiros no mesmo sentido:

19 Op. cit. nota 17, p. 673.

20 DINIZ, Maria Helena. Código Civil anotado. 4. ed. São Paulo: Saraiva, 1998, p. 31.

21 Manual de direito administrativo. Rio de Janeiro: Renovar, 1997, p. 298.

22 DIAS. José de Aguiar. Da responsabilidade civil. 6. ed. rev. aum. Rio de Janeiro: Forense, 1979, p. 664. 
RESPONSABILIDADE CIVIL DO PODER PÚBLICO — REVOLTA DA POPULAÇÃO - BOMBA - CULPA — Para obter a indenização contra o Estado por ter o autor sido atingido por uma bomba durante incidentes de revolta da população pela majoração das passagens de ônibus, necessária se faz a comprovação da culpa do Estado no fato (TJ RJ, Ap. 4545/90 - $6^{\text {a }}$ C.Civ. - Rel. Dês. Pestana de Aguiar - julg. 19.3.91).

Prestação de serviço de saúde mantido em hospital municipal - Necessidade da comprovação da ocorrência de comissão ou omissão decorrente de imprudência, negligência ou imperícia quer por parte do médico, quer por parte da pessoa jurídica de direito público (TJSP, RT 775/247).

\subsection{A responsabilidade estatal objetiva por conduta omissiva defendida pela doutrina e jurisprudência majoritárias.}

Toshio MUKAI observa. com propriedade, o conceito de causa:

As obrigações, em direito, comportam causas, podendo estas ser a lei, o contrato ou o ato ilícito. Ora, causas, nas obrigações jurídicas (e a responsabilidade civil é uma obrigação), é todo o fenômeno de transcedência jurídica capaz de produzir um poder jurídico pelo qual alguém tem o direito de exigir de outrem uma prestação (de dar, de fazer, ou de não fazer $)^{23}$.

José de Aguiar DIAS, adepto da responsabilidade objetiva, ao expor o seu entendimento sobre o termo causa, assim preceituou:

Só é causa aquele fato a que o dano se liga com força de necessidade. Se numa sucessão de fatos, mesmo culposos, apenas um, podendo evitar a consequiência danosa, interveio e correspondeu ao resultado, só ele é causa, construção que exclui a polêmica sobre a mais apropriada adjetivação. Se ao contrário, todos ou alguns contribuíram para o evento, que não ocorreria, se não houvesse a conjugação deles, esses devem ser considerados causas concorrentes ou concausas ${ }^{24}$.

Desta forma, conclui Aguiar DIAS que a inércia do Estado empenha responsabilidade civil a este e a consequiente obrigação de reparar integralmente o dano causado, na forma do artigo 37 parágrafo $6^{\circ}$ da Constituição Federal, portanto, a responsabilidade é objetiva.

Odete Medauar entende que a responsabilidade do Estado, fundamentada na Teoria do Risco Administrativo, apresenta-se, hoje, na maioria dos ordenamentos

23 MUKAI, Toshio apud LAZZARINI, Álvaro. Responsabilidade civil do Estado por atos omissivos dos seus agentes. Revista de Jurisprudência do Tribunal de Justiça de São Paulo. São Paulo, n. 117 , p. 16.

24 Da responsabilidade civil, op. cit. nota 22, p. 252. 
jurídicos, regida pela Teoria da Responsabilidade Objetiva. Entende, ainda, que a adoção da responsabilidade objetiva do Estado traz, por conseguinte, o sentido de igualdade de todos ante os ônus e encargos deste e o próprio sentido de justiça [eqüidade]. Acrescenta que como nem sempre é possivel identificar o agente causador do dano, nem demonstrar o dolo ou culpa, melhor se asseguram os direitos da vítima através da aplicação da responsabilidade objetiva ao Estado ${ }^{25}$.

Quanto ao preceito da igualdade de todos ante os ônus e encargos públicos, também denominado "solidariedade", ensina: "Se, em tese, todos se beneficiam das atividades da Administração. todos [representados pelo Estado] devem compartilhar do ressarcimento dos danos que essas atividades causam a alguém" 26 .

Na mesma linha de raciocínio Celso Ribeiros BASTOS analisa a responsabilidade do Estado, ensinando que tal entendimento já se encontra sedimentado atualmente e, não há, portanto, que se questionar sobre o elemento subjetivo da culpa entre o dano e o comportamento que o provocou ${ }^{27}$.

Hely Lopes MEIRELLES, da mesma forma, defende a tese da responsabilidade objetiva, dispondo que esta se fundamenta no risco proveniente de sua ação ou omissão, que visam à consecução de seus fins ${ }^{28}$.

Preleciona Weida Zancaner BRUNINI que a teoria objetiva é aplicada na responsabilidade do Estado. Porém, a teoria subjetiva ainda permanece na relação Estado-funcionário, quanto ao direito de regresso do Estado contra seu agente, pois condicionada está à culpabilidade deste ${ }^{29}$.

Yussef Said CAHALI também é no sentido de que o artigo constitucional acolhe, sob o manto da responsabilidade objetiva, tanto a conduta omissiva quanto a comis$\operatorname{siva}^{30}$

A jurisprudência pátria é majoritária no sentido de que a responsabilidade do Estado por conduta omissiva é objetiva. Com efeito, os julgados abaixo denotam o exposto:

RESPONSABILIDADE CIVIL DO ESTADO - MORTE DE DETENTO. $O$ ordenamento constitucional vigente assegura ao preso a integridade física (CF art. 5, XLIX) sendo dever do Estado garantir a vida de seus detentos, mantendo, para isso, vigilância constante e eficiente. Assassinado o preso por colega de cela quando cumpria pena por homicídio qualificado responde o estado civilmente pelo evento danoso, independentemente da culpa do agente público. Recurso improvido. Por unanimidade, negar provimento ao recurso. (STJ, RESP 5711, decisão 20.03.1991, Ministro Garcia Vieira).

25 Direito administrativo modeno. 4. ed. São Paulo: Revista dos Tribunais, 2000, p. 430.

26 Ibidem. p. 431.

27 Curso de direito administrativo. 3 ed. São Paulo: Saraiva, 1999, p. 190.

28 Op. cit., p. 536.

29 Da responsabilidade extracontratual da administração pública. São Paulo: Revista dos Tribunais, 1981, p. 32.

30 Responsabilidade civil do Estado. 2. ed. São Paulo: Malheiros, 1995, p. 40. 
RESPONSABILIDADE CIVIL DO ESTADO - MÁ EXECUÇÃO DOS SERVIÇOS PÚBLICOS - RISCO ADMINISTRATIVO - DANO E NEXO DE CAUSALIDADE. A responsabilidade civil das pessoas jurídicas de direito público, responsabilidade objetiva, com base no risco administrativo, que admite pesquisa em torno da culpa do particular, para o fim de abrandar ou mesmo excluir a responsabilidade estatal, ocorre, em síntese, diante dos seguintes requisitos: a) do dano; b) da ação administrativa (comissiva ou omissiva); c) do nexo causal entre o dano e a ação administrativa. - O Município tem, por obrigação, manter em condições de regular o uso e sem oferecer riscos, as vias públicas e logradouros abertos à comunidade

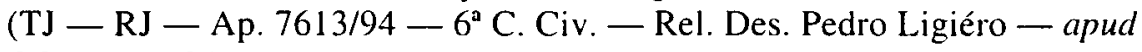
COAD 75286).

Indenização - Acidente de Trânsito - Sinistro ocasionado pela falta de serviço na conservação de estrada - Ausência de prova de culpa do particular, bem como de evento tipificador de força maior - Comprovação do nexo de causalidade entre a lesão e o ato da Administração - Verba devida - Aplicação da teoria do risco administrativo, nos termos do art. $37, \S 6^{\circ}$, da CF (TJMG, RT 777/365).

Por esses entendimentos, podemos concluir que o comportamento omissivo do Estado deve ser considerado como causa do dano, e não simples condição deste, como entende a corrente doutrinária subjetivista, anteriormente citada. Portanto, o parágrafo $6^{\circ}$ do artigo 37 da Constituição federal contempla, além da responsabilidade por atos comissivos, aquela decorrente da conduta omissiva.

\subsection{Considerą̧ões sobre a natureza objetiva da responsabilidade estatal por conduta omissiva}

Como se verificou, os autores pátrios, no que tange à natureza da responsabilidade do Estado por conduta comissiva, põem-se de acordo. Todavia, no que pertine à conduta omissiva, dividem-se em dois grupos: os que defendem a natureza objetiva dessa responsabilidade e os que a entendem subjetiva. No primeiro grupo estão autores como Yussef Said Cahali, Odete Medauar, Álvaro Lazzarini, Carvalho Filho e Celso Ribeiro Bastos, entre outros; no segundo, Celso Antonio Bandeira de Mello, Maria Sylvya Zanella Di Pietro, Lucia Valle Figueiredo e outros.

A verdade é que o primeiro dos deste último grupo adotou, quanto ao tema, a ensinança de seu pai, Osvaldo Aranha Bandeira de Mello, e, os demais, por sua vez, o seguiram.

O próprio Celso Antonio, quando analisa os danos decorrentes de atividades perigosas do Estado, afirma categoricamente que mesmo as condutas que não estejam diretamente ligadas ao dano entram "decisivamente em sua linha de causação" ${ }^{31}$.

31 Idem, ibidem. p. 628. 
Diz ele: "há determinados casos a ação danosa, propriamente dita, não é efetuada por agente do Estado, contudo é o Estado quem produz a situação da qual o dano depende" ${ }^{32}$. O próprio autor apresenta exemplos. Vejamos um: o assassinato de um presidiário por outro presidiário. Não foi o Estado, mas sim o presidiário, o autor do dano: todavia, foi aquele quem criou as condições para que este dano ocorresse, mantendo-os presos. Ora, se o Estado tivesse cuidado para que a segurança do presidiário fosse adequada, o dano poderia ter sido evitado. Logo, o Estado, também aí, a par de manter preso o autor do dano e a vítima [conduta positiva], omitiu-se quanto à segurança desta última em face daquele [conduta omissiva]. A primeira delas, para o autor, é causa do dano, a segunda, não.

Agostinho ALVIM acentua que a "teoria da equivalência das condições aceita qualquer das causas como eficiente". asseverando que essa "equivalência resulta de que, suprimida uma delas, o dano não se verificaria" 33 .

Yussef Said CAHALI ensina que "não parece haver dúvida de que a responsabilidade civil do Estado pode estar vinculada a uma conduta ativa ou omissiva da Administração, como causa do dano reclamado pelo ofendido" ${ }^{34}$. Logo em seguida, depois de transcrever ensinamentos de CELSO ANTONIO e Álvaro LAZZARINI, alude a que "substancialmente, tais manifestações não se revelam conflitantes, sendo mais aparente o confronto que se pretende, em especial quando se considera que a própria filosofia jurídica está longe de definir a discriminação conceitual entre 'causa' e 'condição"' 35 .

Álvaro LAZZARINI contesta a assertiva de que a conduta comissiva possa ser causa do dano e a omissiva, não ${ }^{36}$. CAHALI, sintetizando o pensamento de LAZZARINI, afirma que para esse autor:

Causa, nas obrigações jurídicas, é todo fenômeno de transcendência jurídica capaz de produzir um efeito jurídico pelo qual alguém tem o direito de exigir de outrem uma prestação [de dar, de fazer ou não fazer]; daí concluir que a omissão pode ser causa e não condição, ou, em outros termos, o comportamento omissivo do agente público, desde que deflagador primário do dano praticado por terceiro, é causa e não simples condição do evento danoso $0^{37}$.

Veja-se que no exemplo citado por Celso Antonio tanto a conduta comissiva, quanto a omissiva, se eliminada, afastaria o dano. Por que, então, tratá-las de modo diverso? Não existe argumento de ordem filosófica para tanto. Nem o há de ordem jurídica. Vejamos:

32 Idem, ibidem, p. 628.

33 ALVIN, Agostinho. Da inexecução das obrigações e suas conseqüências. 4. ed. atual. São Paulo: Saraiva, 1972, p. 345.

34 CAHALI, Yussef Said, op. ci. nota 30, p. 282.

35 Idem, ibidem, p. 285.

36 Op. cit. nota 23, p. 8-26.

37 CAHALI, Yussef Said. op. cit. nota 30, p. 285. 
A Constituição Federal, no artigo citado, não diferenciou as duas condutas, quando poderia perfeitamente fazê-lo. Assim, o vocábulo "causarem", do aludido dispositivo, deve ser lido como "causarem por ação ou omissão".

Entender-se que o legislador brasileiro, muito bem informado, à época, da evolução do instituto, teria recuado no tempo, estabelecendo a responsabilidade objetiva apenas para os casos de conduta comissiva, retroagindo, no que tange à omissiva, aos tempos da culpa civilística ou da faute du service, seria demasiado. Aliás, a responsabilidade objetiva já vinha consagrada no direito brasileiro desde a Constituição Federal de 1946 [art. 194] ${ }^{38}$. Por que, então, o legislador constitucional, ao invés de avançar, teria preferido recuar, distinguindo as duas condutas? Qual o fundamento, legal e político, para a distinção?

Note-se que no que concerne ao agente estatal causador do dano o constituinte avançou substituindo a expressão "funcionário" por "agente", muito mais abrangente. Estendeu a responsabilidade também para os particulares prestadores de serviço público [a chamada desestatização apenas engatinhava]. Ora, por que, então, no que tange à conduta do agente, aquele teria recuado quase um século, para, a par da responsabilidade objetiva, fixada para a conduta comissiva, estatuir a responsabilidade subjetiva em caso de conduta omissiva?

O que se pretendeu com toda a evolução da responsabilidade do Estado foi exatamente evitar que o lesado tivesse de provar a culpa do agente, nem sempre e quase nunca - um exercício fácil. Por que o legislador, cônscio dessa evolução, teria marchado em ré? Especialmente quando ele mesmo, legislador constitucional, previu a responsabilidade objetiva, com o mesmo desiderato, para questões relacionadas com o meio ambiente e com os direitos do consumidor? Implica, tal conclusão, num contra-senso!!! Até porque, na omissão, em regra, é muito mais difícil a prova da culpa.

Ao final, parece ser mesmo despicienda a discriminação entre causa e condição como fatores ensanchadores da responsabilidade estatal.

Ademais, o ensinamento de Celso Antonio baseia-se em que, para ele, a conduta omissiva da Administração é sempre ilícita. Parte da idéia de que a responsabilidade do Estado nasce do fato de que este, tendo o dever de agir, não agiu. Logo, descumpriu um dever legal; agiu ilicitamente. Ora, mesmo firmado tal entendimento - e parece ser este o predominante - - , não estaria afastada a responsabilidade objetiva da Administração omissa. A responsabilidade continuaria sendo objetiva, por força de disposição constitucional expressa, cabendo ao lesado demonstrar a conduta [no caso, omissiva] do agente estatal, o dano e o nexo de causalidade entre eles, e, àquela, demonstrar que não tinha o dever legal de agir, ou que, o tendo, não deixou de agir ou, ainda, que está presente qualquer das excludentes de responsabilidade, o que afastaria a obrigação de indenizar. Note-se que não é necessário transmudar a responsabilidade objetiva em subjetiva para que a Administração se desvincule do

38 MEIRELLES, Hely Lopes, op. cit. nota 14, p. 534; e CRETELLA JUNIOR, José. Direito administrativo brasileiro. Rio de Janeiro: Forense, 1999, p. 684, entendem que o art. 194 da Constituição Federal de 1946 revogou o art. 15 do antigo Código Civil, já que com ele incompatível. 
dever de indenizar: basta que esta demonstre que não tinha o dever de agir e que, portanto, sua conduta não foi, do ponto de vista jurídico, causa do evento danoso.

CAHALI informa que:

[...] notoriamente elástico o conceito de exigibilidade do ato estatal, no caso, a carga de subjetivismo que caracteriza a sua identificação é que terá induzido alguns autores ao exame das hipóteses da perspectiva da responsabilidade subjetiva do Estado, com perquirição necessária do elemento 'culpa ou dolo, 3 .

E arremata: "[...] portanto, o dever jurídico descumprido, de execução de obra ou prestação do serviço devido, colocado como causa primária da responsabilidade estatal, é circunstancial e contingente" ${ }^{40}$.

Importante salientar que Celso Antonio entende que a conduta comissiva decorrente de ato ilícito - insista-se: ilícito - gera responsabilidade objetiva. Adverte ele que às vezes a conduta estatal causadora do dano é ilegítima e, nesse caso, não haverá lugar para variar as condições de aplicação da responsabilidade do Estado. Afirma, com todas as letras. " $[. .$.$] deveras, se a conduta legítima produtora de dano$ enseja responsabilidade objetiva, a fortiori deverá ensejá-la a conduta ilegítima causadora de lesão injurídica [...] saber-se se o Estado agiu ou não culposamente [ou dolosamente] é questão irrelevante" +1 .

Entretanto, quando defende a natureza subjetiva da responsabilidade do Estado por conduta omissiva, o mesmo autor assevera que " [...] sendo responsabilidade por ilícito, é necessariamente responsabilidade subjetiva" 42 .

É de se indagar por que na conduta comissiva ilícita não se discute dolo ou culpa - responsabilidade objetiva — e na conduta ilícita omissiva aqueles elementos subjetivos são discutidos - responsabilidade subjetiva? Seria apenas porque na primeira a conduta estatal é causa do dano e, na segunda, mera condição? Essa distinção, como se asseverou, já não se sustenta cientificamente. Logo, há de ser afastada.

Com efeito, alijada a dicotomia entre causa e condição, o dano, resultante de conduta estatal, comissiva ou omissiva, deve ser reparado pelo Estado, sem que se possa debater sobre a existência ou não culpa. Portanto, responsabilidade objetiva.

Demais disso, há autores que sustentam que a omissão do agente estatal pode, sim, ser causa do dano. Entre eles Rui STOCO, que ensina: "Não é apenas a ação que produz dano. Omitindo-se o agente público também pode causar prejuízo ao administrado e à própria Administração" ${ }^{3}$.

39 Idem, ibidem, p. 286.

40 Idem. ibidem, p. 287.

4 Op. cit. nota 17, p. 623.

42 Idem, ibidem. p. 624.

43 Responsabilidade civil. 3. ed. rev. ampl. São Paulo: Revista dos Tribunais, 1997, p. 572. 
Lazzarini diz que o Estado responde, objetivamente, sempre que demonstrado o nexo de causalidade entre o dano e a atividade funcional do agente estatal, só podendo haver discussão sobre culpa ou dolo na ação regressiva do Estado contra o agente causador do dano, acrescentando que não é somente a ação, mas também a omissão, que pode causar dano suscetível de reparação por parte do Estado ${ }^{44}$. O mesmo autor indica vários casos em que os tribunais pátrios entenderam que a omissão de agente do Estado foi causa do dano, decidindo por impor a este o dever de indenizar ${ }^{45}$.

Imagine-se a situação em que um médico, no desempenho de função estatal, deixe de socorrer um paciente e este, em razão da omissão daquele, vem a morrer. Não terá sido a omissão do médico [agente estatal] a causa do dano? Será possível justificar, nesta hipótese, que para a causação do dano a conduta omissiva atuou à guisa de mera condição?

Não parece ter cabida uma outra afirmação do mesmo autor, no sentido de que nos casos de responsabilidade do Estado por conduta omissiva a questão deve ser analisada e decidida pelo ângulo da Administração, ou seja, pelo lado ativo da relação, ao passo que quanto à conduta comissiva a análise e a decisão devem centrar-se no lesado, isto é, no lado passivo da relação ${ }^{46}$.

Ora, em qualquer caso de responsabilidade do Estado, seja por conduta comissiva, seja por omissiva, há vários elementos que devem ocupar o cenário: o dano, a conduta estatal e o nexo de causalidade. Outros, ainda, poderão ter lugar na discussão: a presença de circunstâncias excludentes, o fato de o dano não ser especial e anormal, a inexistência do dever de agir etc.

Assim, não se pode falar que na responsabilidade decorrente de conduta comissiva analisa-se a questão pelo lado do lesado, quando, em se tratando de conduta omissiva, essa análise estaria centrada no lado da Administração. Em ambos os casos, vários fatores entram em linha de conta, sem preponderância de qualquer deles. Em ambos, será de fundamental importância, por exemplo, a imputação do dano à conduta estatal [comissiva ou omissiva] e sua qualificação [especial e anormal], bem como o fato de que o sujeito lesado não está obrigado a suportá-lo. Por conseguinte, o argumento não impressiona.

Derradeiramente, há de ser analisada a afirmação, também feita por Celso Antonio, de que se nos danos decorrentes de conduta estatal omissiva o Estado for chamado a responder objetivamente este estará sendo erigido à condição de segurador

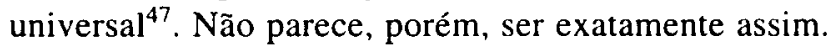

Ocorre que em todos os casos em que o Estado é chamado a ressarcir prejuizos decorrentes de conduta omissiva, bem assim nas comissivas, poderá ele defender-se

Estudos de direito administrativo. 2. ed. São Paulo: Revista dos Tribunais, 1999, p. 443.

Idem, ibidem, p. 429.

Idem, ibidem, p. 626.

MELLO, Celso Antônio Bandeira de, op. cit., nota 17, p. 626. 
demonstrando a presença de quaisquer das circunstâncias excludentes de responsabilidade. Poderá, ainda, demonstrar que o dano não é especial nem anormal ou que não tinha o dever de agir. Este largo espectro de defesa leva à conclusão de que mesmo que se aplique, em todos os casos, a teoria do risco administrativo e, portanto, a responsabilidade objetiva, o Estado não estará sendo erigido à condição de segurador universal. Ademais, se o Estado se omite no seu dever de agir conforme os padrões médios de exigência da população, assim causando lesões ao patrimônio das pessoas, melhor seria mesmo que fosse erigido a tal condição. Não é este, contudo, o caso.

O Supremo Tribunal Federal já teve o ensejo de aclarar a situação, em percuciente voto do Ministro Celso de $\mathrm{Mello}^{48}$.

A razão está mesmo com Odete MEDAUAR, que argumenta, em preciosa síntese:

Informada pela teoria do risco, a responsabilidade do Estado apresenta-se hoje, na maioria dos ordenamentos, como responsabilidade objetiva. Nessa linha, não mais se invoca o dolo ou culpa do agente, o mau funcionamento ou falha da Administração. [...] Deixa-se de lado, para fins de ressarcimento do dano, o questionamento do dolo ou culpa do agente, o questionamento da licitude ou ilicitude da conduta, o questionamento do bom ou mau funcionamento da Administração. Demonstrado o nexo de causalidade, o Estado deve ressarcir ${ }^{49}$.

A evolução da responsabilidade do Estado, no sentido de sua objetivação, fica ainda mais evidente quando se constata a redação, como se segue, do art. 43 do novel Código Civil, que entrou em vigor no dia 11 de janeiro de 2003.

48 "A teoria do risco administrativo, consagrada em sucessivos documentos constitucionais brasileiros desde a Carta Política de 1946, confere fundamento doutrinário à responsabilidade civil objetiva do Poder Público pelos danos a que os agentes públicos houverem dado causa, por ação ou por omissão. Essa concepção teórica, que informa o princípio constitucional da responsabilidade civil objetiva do Poder Público, faz emergir, da mera ocorrência de ato lesivo causado à vítima pelo Estado, o dever de indenizá-la pelo dano pessoal e/ou patrimonial sofrido, independentemente de caracterização de culpa dos agentes estatais ou de demonstração de falta do serviço público. Os elementos que compõem a estrutura e delineiam o perfil da responsabilidade civil objetiva do Poder Público compreendem a) a alteridade do dano, b) a causalidade material entre o 'eventus damini' e o comportamento positivo [ação] ou negativo [omissão] do agente público, c) a oficialidade da atividade causal e lesiva, imputável a agente do Poder Público, que tenha, nessa condição funcional, incidido em conduta comissiva ou omissiva, independentemente da licitude, ou não, do comportamento funcional [RTJ 140/636] e d) a ausência de causa excludente da responsabilidade estatal [RTJ 55/503 - RTJ 71/99 - RTJ 91/377 - RTJ 99/1155 - RTJ 131/417]. O princípio da responsabilidade objetiva não se reveste de caráter absoluto, eis que admite o abrandamento e, até mesmo, a exclusão da própria responsabilidade civil do Estado, nas hipóteses excepcionais configuradoras de situações liberatórias - como o caso fortuito e a força maior - ou evidenciadoras de ocorrência de culpa atribuível à própria vítima" [RDA 137/233 - RTJ 55/50 - STF - RE 109.615 - RJ - $1^{\mathrm{a}}$ T. - Rel. Min. Celso de Mello - DJU 02.08.1996].

49 Op. cit. nota 25 , p. 430. 
Art. 43 - As pessoas jurídicas de direito público interno são civilmente responsáveis por atos dos seus agentes que nessa qualidade causem danos a terceiros, ressalvado direito regressivo contra os causadores do dano, se houver, por parte destes, culpa ou dolo.

Fica absolutamente claro que o legislador contemplou, mais uma vez, a responsabilidade objetiva do Estado - embora já não fosse necessário fazê-lo —, permitindo a perquirição sobre a presença do elemento subjetivo [culpa ou dolo] tão-somente na ação regressiva [do Estado] em face do [agente] causador do dano.

Concluindo, pode-se afirmar que o legislador brasileiro, bem como a doutrina e a jurisprudência, sempre tiveram clara a evolução da responsabilidade do Estado, sempre no sentido de sua objetivação, afastando-se da culpa e aproximando-se do risco, até assumi-lo, sendo razoável que se falasse em algum tipo de responsabilidade subjetiva apenas no período que vai do início de vigência do antigo Código Civil de 1916 até a promulgação da Constituição Federal de 1946, quando, promulgada esta, a responsabilidade do Estado passou a ser objetiva, ficando revogado o Código Civil.

\subsection{O princípio da legalidade e a conduta omissiva}

O princípio da legalidade é considerado como sendo o princípio maior que rege os atos administrativos, praticados pelo Estado. Exige ele que a administração pública somente poderá fazer ou deixar de fazer algo, desde que prescrito por lei. Ocorre, porém, que em sua grande maioria os atos administrativos são atos vinculados. Mesmo nos atos discricionários também pesa tal princípio, visto que a margem de liberdade de decisão que a norma autoriza ao agente possui, sempre, um limite, posto pela própria norma.

$\mathrm{Na}$ responsabilidade do Estado por conduta omissiva, o agente tem o dever de agir, estabelecido em lei, mas, desobedecendo à lei, não age. Por não ter agido, causou um dano ao particular. Portanto, trata-se de uma conduta ilícita, isto é, contrária à lei. Logo, feriu-se o princípio da legalidade.

Como o interesse social tem por objetivo a manutenção da ordem pública no sentido de viabilizar a harmonia social, importante ressaltar a gravidade de uma conduta ilícita e omissiva. $\mathrm{O}$ ato ilícito corresponde ao que a sociedade repudia como comportamento, isto é, o que não é aceito no grupo social. Por isso, é o mesmo que estar violando os valores deste grupo. Da mesma forma, o risco social que apresenta a conduta omissiva é de gravidade muito mais elevada.

A doutrina majoritária - inclusive BANDEIRA DE MELLO - entende ser objetiva a responsabilidade decorrente do dano provocado por ato lícito do Estado. Se ato lícito é o ato que está em conformidade com o direito, ou seja, aquilo que é entendido como adequado, correto, bem visto pela sociedade, e, para esse, a responsabilidade é objetiva, porque para o ato ilícito omissivo não haveria também essa maior proteção ao administrado, sendo que este último é indiscutivelmente mais grave?

Destarte, é imperiosa a proteção do administrado contra condutas mais graves, ampliando o seu campo de amparo pela adoção da responsabilidade objetiva. 


\subsection{A Falta do serviço e o Código de Defesa do Consumidor}

O Código de Defesa do Consumidor, em seu artigo 14, combinado com o artigo $3^{\circ}$, atribui ao Estado, enquanto fornecedor de serviço público, a responsabilidade objetiva por danos decorrentes da "falta do serviço público", incluindo, assim, a responsabilidade por conduta omissiva.

Assim, o Estado é considerado fornecedor de serviço público, devendo, portanto. obedecer a todos os princípios e regras protetores do consumidor, inclusive ao princípio contido no inciso $\mathrm{X}$ do artigo $6^{\circ}$ do $\mathrm{CDC}$, que expressamente determina ser direito do consumidor "a adequada e eficaz prestação dos serviços públicos em geral".

O Artigo 22 do mesmo diploma legal dispõe que a responsabilidade pelo fornecimento inadequado ou ineficaz do serviço público será regida pelas regras deste código. Portanto, responsabilidade objetiva. ${ }^{50}$.

O doutrinador Zelmo DENARI, com propriedade, explica que: "As pessoas jurídicas de direito público - centralizadas ou descentralizadas - podem figurar no pólo ativo da relação de consumo, como fornecedor de serviços. Por via de conseqüência, não se furtarão a ocupar o pólo passivo da correspondente relação de responsabilidade" 51 .

De acordo com o Código de Defesa do Consumidor, são responsáveis objetivamente a União, os Estados, os Municípios e o Distrito Federal. Também o são as autarquias, as fundações públicas, as sociedades de economia mista, as empresas públicas e as concessionárias e permissionárias de serviço público.

Importante salientar que o Estado somente será considerado fornecedor e, portanto, estará sujeito às regras do Código de Defesa do Consumidor [responsabilidade objetiva] quando for produtor de bens ou prestador de serviços, remunerados por "tarifas" ou "preços públicos". Por outro lado, não serão aplicadas as normas do $\mathrm{CDC}$ aos casos em que aquele for remunerado mediante atividade tributária em geral [impostos, taxas e contribuições de melhoria].

Portanto, a partir do advento do Código de Defesa do Consumidor, a responsabilidade do Estado, pelo serviço público remunerado por tarifa ou preço público, é de natureza objetiva, tanto para as condutas comissivas como para os omissivas.

\section{Conclusões}

1 - A responsabilidade civil é um instituto de difícil conceituação, por sua amplitude. Tem por finalidade o restabelecimento do equilíbrio violado pelo dano.

so Art. 22. CDC: "Os órgãos públicos, por si ou suas empresas, concessionárias, permissionárias ou sob qualquer outra forma de empreendimento, são obrigadas a fornecer serviços adequados, eficientes, seguros e, quanto aos essenciais, contínuos. Parágrafo único - Nos casos de descumprimento, total ou parcial, das obrigaçōes referidas neste artigo, serão as pessoas jurídicas compelidas a cumpri-las e reparar os danos causados, na forma prevista neste Código".

5! GRINOVER, Ada Pellegrini et al. Código brasileiro de defesa do consumidor: comentado pelos autores do anteprojeto. 6. ed. Rio de Janeiro: Forense Universitária, 1999, p. 190. 
Quanto ao seu fundamento, a responsabilidade civil poderá ser: a) subjetiva: presente sempre o pressuposto culpa ou dolo; por isso, para sua caracterização devem coexistir os seguintes elementos: a conduta, o dano, a culpa e o nexo de causalidade entre a conduta e o dano. É a Teoria da Culpa, também chamada de responsabilidade aquiliana; b) objetiva: não há a necessidade da prova da culpa, bastando a existência do dano, da conduta e do nexo causal entre o prejuízo sofrido e a ação do agente; está calcada no risco assumido pelo lesante, em razão de sua atividade, daí ser chamada também de Teoria do Risco.

2 - Em nosso ordenamento jurídico já é pacífico o entendimento de que o Estado é responsável por suas condutas, comissivas ou omissivas, que causarem danos e terceiros, porém essa responsabilidade traz em seu bojo regras peculiares.

3 - O Estado poderá excluir a sua responsabilidade quando ocorrerem determinadas situações, que, na verdade, retiram o nexo de causalidade entre a conduta estatal e o dano. São elas: força maior, caso fortuito, estado de necessidade e culpa exclusiva da vítima ou de terceiro.

4 - A doutrina e a jurisprudência brasileiras são unânimes quanto à natureza objetiva da responsabilidade do Estado por conduta comissiva. Porém, quanto às condutas omissivas, o direito pátrio traz duas correntes divergentes. A primeira, capitaneada por Oswaldo Aranha Bandeira de Mello e continuada por Celso Antônio BANDEIRA DE MELLO, aponta a responsabilidade do Estado como sendo de natureza subjetiva, com base no artigo 15 do antigo Código Civil [art. 43 do novo Código]. A segunda corrente, que sustenta ser a responsabilidade objetiva, é seguida pelos doutrinadores Odete MEDAUAR, Celso Ribeiro BASTOS, Álvaro LAZZARINI, Aguiar DIAS, Hely Lopes MEIRELLES, Weida Zancaner BRUNINI, Yussef Said CAHALI, entre outros, e fundamenta-se no artigo $37, \S 6^{\circ}$, da Constituição Federal.

5 - Celso Antônio BANDEIRA DE MELLO, a fim de justificar a aplicação da Teoria Subjetiva à responsabilidade do Estado por conduta omissiva, argumenta que a palavra "causarem" do artigo 37 , parágrafo $6^{\circ}$, da Constituição Federal somente abrange os atos comissivos, e não os omissivos, afirmando que estes apenas "condicionam" o evento danoso, ou seja, são apenas "condição", e não "causa", do dano, pois causa é o fato que positivamente gera um resultado e condição é o evento que não ocorreu, mas que, se tivesse ocorrido, teria impedido o resultado.

6- A outra corrente, que sustenta ser a responsabilidade do Estado por conduta omissiva regida pela Teoria do Risco, fundamentada no artigo $37, \S 6^{\circ}$, da $\mathrm{CF}$, contraria os argumentos de Celso Antônio BANDEIRA DE MELLO, afirmando que a conduta omissiva estatal não pode ser considerada condição, mas sim causa, pois esta é todo fenômeno capaz de produzir um poder jurídico pelo qual alguém tem o direito de exigir de outrem uma prestação [de dar, de fazer, ou de não fazer].

7 - Celso Antonio BANDEIRA DE MELO, quando analisa os danos decorrentes de atividades perigosas do estado, afirma categoricamente que mesmo as condutas que não estejam diretamente ligadas ao dano entram "decisivamente em sua linha de causação" 52. Diz ele: "há determinados casos em que a ação danosa, 
propriamente dita, não é efetuada por agente do Estado, contudo é o Estado quem produz a situação da qual o dano depende" $\$ 3$.

8 - A Constituição Federal, no artigo citado, não diferenciou as condutas comissivas e omissivas; assim, o vocábulo "causarem", do aludido dispositivo, deve ser lido como "causarem por ação ou omissão", pois caso contrário o legislador teria recuado no tempo, estabelecendo a responsabilidade objetiva apenas para os casos de conduta comissiva, o que é inconcebível, diante dos avanços em outras matérias constitucionais, tais como a substituição da expressão "funcionário" por "agente", muito mais abrangente, e a extensão da responsabilidade também para os particulares prestadores de serviço público [a desestatização apenas engatinhava].

9 - Para Celso Antonio, a conduta omissiva da Administração é sempre ilícita. Mesmo firmado tal entendimento, não estaria afastada a responsabilidade objetiva da Administração omissa, pois a responsabilidade continuaria sendo objetiva, por força de disposição constitucional expressa. Não é necessário transmudar a responsabilidade objetiva em subjetiva para que a Administração se desvincule do dever de indenizar; basta que esta demonstre que não tinha o dever de agir e que, portanto, sua conduta não foi, do ponto de vista jurídico, causa do evento danoso.

10 - Celso Antonio entende que a conduta comissiva decorrente de ato ilícito gera responsabilidade objetiva, bem como que às vezes a conduta estatal causadora do dano é ilegítima e, nesse caso, será sempre objetiva a responsabilidade. Entretanto, quando defende a natureza subjetiva da responsabilidade do Estado por conduta omissiva, o mesmo autor se contradiz, ao asseverar que " [...] sendo responsabilidade por ilícito, é necessariamente responsabilidade subjetiva" ${ }^{54}$. É de se indagar: por que na conduta comissiva ilícita não se discute dolo ou culpa — responsabilidade objetiva - e na conduta ilícita omissiva aqueles elementos subjetivos são discutidos responsabilidade subjetiva? Seria apenas porque na primeira a conduta estatal é causa do dano e, na segunda, mera condição? Essa distinção, como se asseverou, já não se sustenta cientificamente, por isso deve ser afastada, prevalecendo a responsabilização objetiva do Estado.

11 - Não se sustenta a outra afirmação do mesmo autor, no sentido de que nos casos de responsabilidade do Estado por conduta omissiva a questão deve ser analisada e decidida pelo ângulo da Administração, ao passo que quanto à conduta comissiva a análise e a decisão devem centrar-se no lesado. Em qualquer caso de responsabilidade do Estado, seja por conduta comissiva, seja por omissiva, haverá sempre os seguintes elementos: o dano, a conduta estatal e o nexo de causalidade. Outros, ainda, poderão ter lugar na discussão: a presença de circunstâncias excludentes, o fato de o dano não ser especial e anormal, a inexistência do dever de agir etc. Assim, não se pode falar que na responsabilidade decorrente de conduta comissiva analisa-se a questão pelo lado do lesado, quando, em se tratando de conduta omissiva, essa análise estaria centrada no lado da Administração. Em ambos os casos, vários fatores entram em linha de conta, sem preponderância de qualquer deles. 
12 - Também foi analisada a afirmação, feita por Celso Antonio, de que se nos danos decorrentes de conduta estatal omissiva o Estado for chamado a responder objetivamente este estará sendo erigido à condição de segurador universal. Em todos os casos em que o Estado é chamado a resarcir prejuízos decorrentes de conduta omissiva, bem assim nas comissivas, poderá ele defender-se demonstrando a presença de quaisquer das circunstâncias excludentes de responsabilidade. Poderá, ainda, demonstrar que o dano não é especial, nem anormal, ou que não tinha o dever de agir. Este largo espectro de defesas leva à conclusão de que mesmo que se aplique a responsabilidade objetiva, o Estado não estará sendo erigido à condição de segurador universal.

13 - A evolução da responsabilidade do Estado, no sentido de sua objetivação, fica ainda mais evidente quando se constata a redação do art. 43, do novo Código Civil de 2002, que deixou absolutamente claro que a perquirição sobre a presença do elemento subjetivo [culpa ou dolo] seria tão-somente na ação regressiva [do Estado] em face do [agente] causador do dano.

14 - O legislador brasileiro, bem como a doutrina e a jurisprudência, sempre tiveram clara a evolução da responsabilidade do Estado, no sentido de sua objetivação, afastando-a da culpa e aproximando-a do risco, até assumi-lo, sendo razoável que se falasse em algum tipo de responsabilidade subjetiva apenas no período que vai do início de vigência do antigo Código Civil de 1916 até a promulgação da Constituição Federal de 1946, quando, promulgada esta, a responsabilidade do Estado passou a ser objetiva, ficando revogado o antigo Código Civil.

15 - A doutrina majoritária, inclusive BANDEIRA DE MELLO, entende ser objetiva a responsabilidade decorrente do dano provocado por ato lícito do Estado. Se ato lícito é o ato que está em conformidade com o direito e, para esse, a responsabilidade é objetiva, por que para o ato ilícito omissivo não haveria também essa maior proteção ao administrado, sendo que este último é indiscutivelmente mais grave? É imperiosa a proteção do administrado contra condutas mais graves, ampliando o seu campo de amparo pela adoção da responsabilidade objetiva.

16 - O Código de Defesa do consumidor atribui ao Estado, enquanto fornecedor de serviço público, a responsabilidade objetiva por danos decorrentes da "falta do serviço público", incluindo, assim, a responsabilidade por conduta omissiva; deve, ainda, obedecer a todos os princípios e regras protetores do consumidor; e, pelo artigo 22, a responsabilidade pelo fornecimento inadequado ou ineficaz do serviço público será de natureza objetiva. Importante salientar que o estado somente será considerado fornecedor e, portanto, estará sujeito às regras do $\mathrm{CDC}$ [responsabilidade objetiva] quando for produtor de bens ou prestador de serviços, remunerados por "tarifas" ou "preços públicos", portanto não serão aplicadas as normas do CDC aos caso em que aquele for remunerado por tributos. Desta forma, a partir do advento do Código de Defesa do Consumidor, a responsabilidade do Estado, pelo serviço público remunerado por tarifa ou preço público, é de natureza objetiva, tanto para as condutas comissivas como para as omissivas.

17 - Ante todos os argumentos expostos, nosso posicionamento é no sentido da aplicabilidade da Teoria do Risco Administrativo, ou seja, da responsabilidade de natureza objetiva ao Estado, pelas condutas omissivas que causarem danos a 
terceiros, haja vista a necessidade de proteger o lesado ante a dificuldade deste em demonstrar a culpa ou dolo de algum agente ou que o serviço não funcionou como deveria. Ademais, o artigo $37, \S 6^{\circ}$. da Constituição Federal é claro ao discorrer que o Estado responde, independente de culpa, pelas condutas comissivas ou omissivas que causarem danos a terceiros. Todos os argumentos utilizados pelos doutrinadores a fim de sustentar a tese de que se aplica a Teoria Subjetiva na responsabilização das condutas omissivas estatais são frágeis e contraditórios. Ademais, o novo Código Civil, ao trazer tal regra no art. 43 , corroborou a norma constitucional, no sentido de que será verificada a culpa ou o dolo somente em ação regressiva do Estado em face do agente causador do dano.

\section{Referências bibliográficas}

ÁLVAREZ, Carlos Lasarte. Principios de derecho civil: drecho de obligaciones. 4. ed. rev. atual. Madrid: Trivium, 1996, tomo 2.

ALVIN, Agostinho. Da inexecução das obrigações e suas conseqüências. 4. ed. atual. São Paulo: Saraiva, 1972.

AMARAL, Francisco. Direito civil. 2. ed. Rio de Janeiro: Renovar, 1998.

BAHIA, Saulo José Casali. Responsabilidade civil do Estado. Rio de Janeiro: Forense. 1997.

BASTOS, Celso Ribeiro. Curso de direito administrativo. 3 ed. São Paulo: Saraiva, 1999.

BITTAR, Carlos Alberto. Curso de direito civil. Rio de Janeiro: Forense Universitária, 1994, v. 1.

BRUNINI, Weida Zancaner. Da responsabilidade extracontratual da administração pública. São Paulo: Revista dos Tribunais, 1981.

CAHALI, Yussef Said. Responsabilidade civil do Estado. 2.ed. São Paulo: Malheiros, 1995.

CARVALHO FILHO, José dos Santos. Manual de direito administrativo. 2. ed. rev. ampl. Rio de Janeiro: Lumen Juris, 1999.

CAVALCANTI, Themistócles. Tratado de direito administrativo. 4. ed. São Paulo: Freitas Bastos, 1960. v. 2.

COSTA, Mário Júlio de Almeida. Direito das obrigações. 6. ed. rev. atual. Coimbra: Almedina, 1994.

CRETELLA JUNIOR, José. Tratado de direito administrativo. Rio de Janeiro: Forense, [s.d.].

Manual de direito administrativo. 3. ed. Rio de Janeiro: Forense, 1984.

Direito administrativo brasileiro. Rio de Janeiro: Forense, 1999.

DIAS, José de Aguiar. Da responsabilidade civil. 6. ed. $\mathrm{r}$ ev. aum. Rio de Janeiro: Forense, 1979.

DINIZ, Maria Helena. Curso de direito civil brasileiro. 12. ed. aum. atual. São Paulo: Saraiva, 1998. v. 7. Código Civil anotado. 4. ed. São Paulo: Saraiva, 1998. 
DI PIETRO, Maria Sylvia Zanella. Direito administrativo. 10. ed. São Paulo: Atlas, 1999.

FIGUEIREDO, Lucia Valle. Curso de direito administrativo. 2. ed. rev. ampl. atual. São Paulo: Malheiros, 1995.

GALLI, Rocco. Corso di diritto amministrativo. 2 ed. rev. ampl. aum. Padova: Sedam, 1994.

GASPARINI, Diogenes. Direito Administrativo. 4. ed. rev. ampl. São Paulo: Saraiva, 1995.

GIL, ANTÔNIO HERNÁNDEZ. Derecho de obligaciones. Madrid: Espasa-Calpe, 1988, tomo III.

GONÇALVES, Carlos Roberto. Responsabilidade civil. 6. ed. São Paulo: Saraiva, 1995.

GRINOVER, Ada Pellegrini et al. Código brasileiro de defesa do consumidor: comentado pelos autores do anteprojeto. 6. ed. Rio de Janeiro: Forense Universitária, 1999.

JORGE, Fernando Pessoa. Ensaio sobre os pressupostos da responsabilidade civil. Coimbra: Almedina, 1995.

LAZZARINI, Álvaro. Responsabilidade civil do Estado por atos omissivos dos seus agentes. Revista de Jurisprudência do Tribunal de Justiça do Estado de São Paulo-RJTJSP. n. 117, p. 8-26.

. Estudos de direito administrativo. 2. ed. São Paulo: Revista dos Tribunais, 1999.

LENZ, Luis Alberto Thompson Flores. A responsabilidade civil do Estado pela prática de ato lícito. Revista da Procuradoria-Geral da República, São Paulo, n. 8, p. 34-40, jan/jn. 1996.

LOPES, Miguel de Serpa. Curso de direito civil. 8. ed. rev. atual. Rio de Janeiro: Freitas Bastos, 196, v. 8.

LUZ, Odília Ferreira da. Manual de direito administrativo. Rio de Janeiro: Renovar, 1997.

MEDAUAR, Odete. Direito administrativo moderno. 4. ed. São Paulo: Revista dos Tribunais, 2000.

MEIRELES, Hely Lopes. Direito administrativo brasileiro. 23. ed. atual. São Paulo: Malheiros, 1998.

MELLO, Celso Antônio Bandeira de. Curso de direito administrativo. 10. ed. São Paulo: Malheiros, 1999.

Responsabilidade patrimonial do Estado por atos administrativos. Revista de Direito Administrativo. Rio de Janeiro, n. 132, p. 41-56, abr. jun. 1978.

MELLO, Oswaldo Aranha Bandeira de. Princípios gerais de direito administrativo. Rio de Janeiro: Forense, 1969, v. 2.

MENDONÇA, Manuel Inácio Carvalho de. Doutrina e prática as obrigações. 4. ed. Rio de Janeiro: Forense, 1956.

MONTEIRO, Wáshington de Barros. Curso de direito civil. 29. ed. atual. São Paulo: Saraiva, 1997, 4. v.

MONTES, Angel Crostobal. La estructura y los sujetos de la obligacion. Madrid: Civitas, 1990. 
MUKAI, Toshio. Direito administrativo sistematizado. São Paulo: Saraiva, 1999.

MUÑOZ, Riánsares López. Dilaciones indebitas y responsabilidad patrimonial de la administración de justicia. Granada: Comares, 1996.

NERY JUNIOR, Nelson. NERY, Rosa Maria de Andrade. Novo Código Civil e legislação extravagante anotados. São Paulo: Revista dos Tribunais, 2002.

NONATO, Orosimbo. Curso de obrigaçōes. Rio de Janeiro: Forense, 1959, v. 2.

PEREIRA. Caio Mário da Silva. Responsabilidade civil. 8. ed. Rio de Janeiro: Forense, 1998.

PÉREZ, Jesús Gonzáles. Responsabilidad patrimonial de las administraciones publicas. Madrid: Editorial Civitas, 1996.

RODRIGUES, Silvio, Direito civil. 14. ed. São Paulo: Saraiva, 1995.

SAMPAIO, Rogério Marrone de Castro. Direito civil: responsabilidade civil. São Paulo: Atlas, 2000.

SCAFF, Fernando Facury. Responsabilidade do Estado intervencionista. São Paulo: Saraiva, 1990.

STOCO, Rui. Responsabilidade civil. 3. ed. rev. ampl. São Paulo: Revista dos Tribunais, 1997.

TÁCITO, Caio. Direito administrativo. São Paulo: Saraiva, 1975.

TELLES, Antônio A. Queiroz. Introdução ao direito administrativo. São Paulo: Revista dos Tribunais, 1995.

THEODORO JUNIOR, Humberto. Responsabilidade civil. Rio de Janeiro: Aide, 1993.

WALD, Arnoldo. Curso de direito civil brasileiro: obrigações e contratos. 14. ed. rev. atual. ampl. São Paulo: Revista dos Tribunais, 2000, v. 2. 